\title{
A Research on the Influence of Scaffolding Teaching on Junior High School Students' English Reading Ability
}

\author{
YANG Dan ${ }^{1}$ \\ ${ }^{1}$ Foreign Language School, Yancheng Teachers University, Jiangsu 224002, China \\ Correspondence: YANG Dan, Foreign Language School, Yancheng Teachers University, Jiangsu 224002, China.
}

Received: June 25, 2021

doi:10.5430/wjel.v11n2p43
Accepted: July 26, $2021 \quad$ Online Published: August 4, 2021

URL: https://doi.org/10.5430/wjel.v11n2p43

\begin{abstract}
This research tries to apply the scaffolding teaching mode in English reading teaching, with the purpose of enhancing students' interest in reading and improving their reading levels. This study explores whether scaffolding teaching can enhance students' reading interest and thus improve junior high school students' English reading ability. After a 3-month-long teaching experiment, through the comparison and analysis of questionnaires and English reading scores, it is found out that scaffolding teaching is beneficial to enhance students' reading interest and improve students' reading level.
\end{abstract}

Keywords: scaffolding teaching mode, English reading ability, reading interest, teaching experiment

\section{Introduction}

In the era of globalization, English has become an important instrument for China to interchange with western countries. Reading is conducive to acquiring information and promoting communication. Therefore, English reading teaching is an important part of improving students' English skills and comprehensive application competency.

In fact, some problems still exist in junior high school English reading teaching. The first problem is the rigidity of traditional teaching methods. Teachers mostly adopt grammar translation methods in class, which focus on transfer of knowledge while ignore the subject status of students. The second problem is the lack of interaction among students. Therefore, students' interest in English reading can't be fully stimulated. Most students exhibit poor performances in communicating with others and thinking in English, which completely deviates from the initial goal and track of language learning and thus leads to low efficiency in English reading. The third problem is the lack of reading strategies. Students can't understand reading materials well and gradually lose interest in reading. These problems interact with each other, leading to poor English reading scores.

\section{Literature Review}

\subsection{Overview of Scaffolding Instruction Research Abroad}

Foreign research on the concept of scaffolding teaching ranges from general definition (Wood Bruner \& Rosses, 1976) to process definition (Cazden, 1979: 23-69) to teaching principles (Hogan \& Pressley, 1997: 13-146) to the relationship between teachers and students (Berk, L, 1995). Researches on scaffolding teaching are more and more in-depth and specific among application scopes (Hobsbaum, 1996), definition of scaffolds (Benson, 1997), rational use of scaffolds (Gibbons, 2002: 44-45) and cooperative learning (Holton and Charke, 2006), which promote the further development of scaffolding teaching. However, in recent years, there have been fewer researches on scaffolding teaching and on junior high school students' English reading.

\subsection{Overview of Scaffolding Instruction Research at Home}

Scaffolding teaching is a new teaching method compared with traditional teaching according to the viewpoint of teaching process (He Kekang, 1997), teaching purpose (Du Jun, 2005), teaching classification (Liu Ying, 2005) and teaching content (Gao Yan, 2012). Scaffolding teaching research ranges from college English writing teaching (Zhang Guorong, 2004) to high school English reading teaching (Han Chengfeng, 2010; Dai Xia, 2012), and effective realization of reading teaching objectives has been explored in this regard as well (Wang Xiaoli, 2018). However, there has been a lack of discussions on reading motivation in junior high school English reading and its influence on students' reading abilities. 


\section{Research Design}

\subsection{Research Questions}

The main purpose of this study is to solve the following questions:

1. Can Scaffolding Instruction enhance junior high school students' interest in English reading?

2. Can Scaffolding Instruction improve junior high school students' English reading level?

\subsection{Research Subjects}

The subjects of this study are students from two parallel classes of Grade 7 in a high school in China. There are 40 students respectively in the two classes. Scaffolding teaching was adopted in Class 1, the experimental class, while the traditional teaching method was adopted in Class 2, the control class. At the same time, almost all students in the two classes have similar English learning backgrounds, and they are taught by the same teacher.

\subsection{Research Instruments}

\subsubsection{Questionnaire}

In order to verify the influence of scaffolding teaching mode on students' learning interest in junior high school English reading teaching, the author conducted an anonymous questionnaire survey among the students in the experimental class and the control class before the experiment. The design of the questionnaire is mainly based on Wen Qiufang's Research methods and case analysis of English teaching (2011: 105-110). The content of the scale is carried out from several aspects, such as students' reading habits, reading initiative and reading purpose. It aims to understand students' reading interest. The questionnaire is edited and published on the website Questionnaire Star, and students are required to fill in the questionnaire according to their actual situation. Therefore, the data obtained are real and effective.

\subsubsection{Tests}

The pre-test was carried out at the beginning of the experiment. The purpose is to know about the current English reading level of the students in the two classes and make sure that they are at the same level. The pre-test paper is selected from the final question bank of their school. At the end of the experiment, the post-test paper was conducted to investigate whether the English reading level of students had changed under different teaching modes. The post-test paper was the final exam of their school, and the structure of the post-test paper was the same as the pre-test paper. The reading section of the paper consists of three English reading passages, with 15 multiple choice questions and a total score of 30 points. It includes various types of reading passages.

\subsubsection{Interview}

At the end of the study, six students from the experimental class were randomly selected as the investigation objects, with the purpose of knowing whether the students' reading ability has been improved under the scaffolding teaching mode.

The interview questions are as follows:

Compared with traditional reading teaching, do you like the Scaffolding Teaching used by teachers in reading class?

1. Do you think this kind of reading teaching mode can really improve your English reading performance and reading ability?

2. Have you gained anything in English reading after applying scaffolding teaching?

\subsection{Research Procedures}

Step 1: Before the experiment, the students of the two classes were given a reading interest survey scale, with the purpose of investigating the current English reading interest of the students of the two classes.

Step 2: Students of the two classes were given a reading test. The reading questions were selected from the reading comprehension part of the final test questions in the research school. The test results of the two classes were compared to further verify that there was no significant difference in the reading ability and English proficiency of the experimental research objects before the start of the experimental study, thus increasing the validity and reliability of the experiment.

Step 3: After the experiment, the same reading interest survey scale was issued to the students of the two classes, and the data of the two classes were analyzed to understand the differences of students' reading interest between the two classes. 
Step 4: To collect effective data and information and understand the specific situation of the application of scaffolding teaching mode in this semester, the students were tested on their reading ability using the final exam paper of their school. After the end of the test, the test results were compared with the previous test results to analyze the difference in scores between the experimental class and the control class after the end of the experimental study, so as to understand the influence of scaffolding teaching mode on the reading scores of junior high school students.

Step 5: After the scaffolding reading teaching experiment, six students selected from the experimental class were interviewed about their feelings of the reading teaching process.

\subsection{English Reading Teaching Case of Experimental Class}

(1) Analysis of teaching content

In order to understand the difference between the scaffolding method and the traditional grammar translation method applied in junior high school English reading teaching, and to introduce the concrete implementation of scaffolding teaching mode in English reading teaching, this study chooses the reading section -- Halloween in Unit 5, Volume 1, Grade 7 of Oxford English as the theme of the teaching case.

This unit describes how to celebrate different festivals. In this unit, students will be able to understand a variety of topics related to festivals. The scaffolding method was adopted in the teaching of English reading in the experimental class. Teachers flexibly build scaffolds for students according to the actual situation in the classroom.

The subjects of this experiment are $7^{\text {th }}$-grade students from a Junior High School in China. The class has a total of 40 students, most of whom are about 13 years old. Their logical thinking ability is initially formed, but the foundation is weak. Students have a certain reading level, but they still need teachers' guidance and supervision.

(2) Teaching Design

(1) Teaching objectives:

Knowledge objectives: Students can understand and master the words and phrases "paint, knock, treat, dress up, play a trick on"; students can understand the meaning of the whole passage, summarize the general idea of each paragraph, and understand related vocabulary about Halloween.

Ability objectives: Students can predict the content based on the title and scan for the detailed information; students can describe exactly how to celebrate Halloween.

Emotional objectives: By learning this article, students can understand the customs of western festivals and respect different cultures.

(2) Key and difficult points:

Help students understand and master basic vocabulary and expressions about Halloween.

How to use different reading skills to get the main information about Halloween.

Teaching method: scaffolding method

(3) Teaching process:

Step 1: Lead in (build a scaffold)

The teacher played a video about Halloween, showed some pictures about it, asked students what they thought of about Halloween and let the students have a group discussion about the date, the custom and the origin step by step. At the end of the discussion, the teacher invited several students to give their opinions.

(Justification: Through the display of videos and pictures, students' interest and curiosity for the topic are aroused so as to have a preliminary understanding of Halloween effectively.)

Step 2: Pre-reading (create a situation)

Teacher creates a situation frame: Supposing Halloween is coming, how would you feel? What do you prepare? Discuss freely for two minutes, then express your own views. According to the students' answers, the teacher introduces the title of the article -- Halloween. The teacher creates a frame of questions and asks the students to guess what they will learn in this lesson.

(Justification: The teacher guides students into the unit theme and creates a specific situation that matches the theme. After helping students understand the background knowledge and theme of this unit, they will enter the situation of reading.) 
Step 3: While-reading (independent exploration)

The teacher gives the students three minutes to read the passage quickly and find out the main idea. After that, the teacher asked three questions. Question 1: When is Halloween? Question 2: How do we celebrate Halloween? Question 3: What will we do when the evening comes? Teacher asks students to answer these three questions to improve their understanding of details. The teacher draws a table on the blackboard while the students answer the questions.

Table 1. Outline of A Passage on the Blackboard

\begin{tabular}{|l|l|}
\hline When & On October 31 \\
\hline How & Dress up, wear masks, paint faces, make pumpkin lanterns \\
\hline What & Visit houses, play a game, have a party \\
\hline
\end{tabular}

(Justification: By asking students to skim the passage and find out the main idea of the passage, we can improve the ability of summarization. Through the three questions, students can understand the content of the passage and clarify the structure of the passage.)

Step 4: Post-reading (cooperative learning)

Teacher lets the students retell the main idea of the passage according to the table drawn on the blackboard. Next, students work in pairs and interview each other.

(Justification: By retelling the passage, the students clear their minds and master the content of the passage. Collaborative learning can stimulate students to discover their own and others' advantages to complete the task of learning, so that their subjectivity has been given full play. The final evaluation helps with students' reflection and correction.)

\section{Step 5: Homework}

Ask students to think about their favorite festivals and why.

\section{Analysis, Discussion and Findings}

\subsection{Analysis of Questionnaires}

4.1.1 Analysis of the Questionnaire before the Experiment

The Questionnaire survey was conducted for all the students in the experimental class and the control class to compare whether the students in the two classes have improved their interest in English reading at the same pace.

Table 2. Analysis of students' interest in English Reading

\begin{tabular}{|c|c|c|c|c|c|c|c|c|}
\hline \multirow{2}{*}{ Question } & \multicolumn{2}{|c|}{1} & \multicolumn{2}{|c|}{2} & \multicolumn{2}{|c|}{3} & \multicolumn{2}{|c|}{4} \\
\hline & $\mathrm{CC}$ & EC & $\mathrm{CC}$ & EC & $\mathrm{CC}$ & EC & CC & EC \\
\hline 1.Are you interested in English reading? & $20 \%$ & $17.5 \%$ & $32.5 \%$ & $30 \%$ & $35 \%$ & $35 \%$ & $12.5 \%$ & $15 \%$ \\
\hline $\begin{array}{l}\text { 2.Do you think English reading is } \\
\text { important? }\end{array}$ & $17.5 \%$ & $15 \%$ & $37.5 \%$ & $35 \%$ & $30 \%$ & $35 \%$ & $15 \%$ & $15 \%$ \\
\hline $\begin{array}{l}\text { 3.Do you actively answer questions in } \\
\text { English reading class? }\end{array}$ & $12.5 \%$ & $12.5 \%$ & $27.5 \%$ & $30 \%$ & $40 \%$ & $37.5 \%$ & $20 \%$ & $20 \%$ \\
\hline $\begin{array}{l}\text { 4.Can you set certain reading goals and } \\
\text { try to achieve them? }\end{array}$ & $7.5 \%$ & $10 \%$ & $25 \%$ & $27.5 \%$ & $47.5 \%$ & $45 \%$ & $20 \%$ & $17.5 \%$ \\
\hline $\begin{array}{l}\text { 5.Do you read English on your own } \\
\text { initiative, even if the teacher doesn't } \\
\text { assign you any tasks? }\end{array}$ & $10 \%$ & $10 \%$ & $25 \%$ & $25 \%$ & $37.5 \%$ & $40 \%$ & $27.5 \%$ & $25 \%$ \\
\hline $\begin{array}{l}\text { 6. When you are reading, will you look up } \\
\text { a new word in the dictionary when you } \\
\text { don't know it? }\end{array}$ & $17.5 \%$ & $15 \%$ & $37.5 \%$ & $35 \%$ & $30 \%$ & $35 \%$ & $15 \%$ & $15 \%$ \\
\hline $\begin{array}{l}\text { 7.After reading, will you find out the } \\
\text { sentences you like in the passage and } \\
\text { memorize them? }\end{array}$ & $7.5 \%$ & $5 \%$ & $17.5 \%$ & $20 \%$ & $30 \%$ & $32.5 \%$ & $45 \%$ & $42.5 \%$ \\
\hline $\begin{array}{l}\text { 8.Do you think the purpose of your } \\
\text { English study is not to let English affect } \\
\text { your total score? }\end{array}$ & $30 \%$ & $35 \%$ & $25 \%$ & $30 \%$ & $25 \%$ & $22.5 \%$ & $20 \%$ & $12.5 \%$ \\
\hline
\end{tabular}


The table above analyzes whether the students of the two classes have a strong interest in English reading. Data show that $20 \%$ of the students in the control class, $17.5 \%$ of the students in the experimental class are very interested in English reading, and about $15 \%$ of the students are not interested in English reading at all. $15 \%$ of the students in the control class and the experimental class think English reading is not important at all, while $45 \%$ of the students think English reading is very important. About $45 \%$ of the students in the two classes are basically unable to set certain reading goals and strive to achieve them. $10 \%$ of the students will take the initiative to read in English when the teacher does not assign homework. Most of the students have the sense of looking up a dictionary when writing reading comprehension. Only $7.5 \%$ of the students in control class, only 5\% of students in the experimental classes will find out their favorite sentences and memorize them after reading. $30 \%$ of the students in the control class think that they learn English in order not to let the English score affect the total score, while only $12.5 \%$ of the students in the experimental class don't think so. It can be seen that most students think that learning English is very important, but they have little interest in English. They will not spend time consolidating their knowledge after class, let alone expand their reading.

\subsubsection{Analysis of the Questionnaire after the Experiment}

Table 3. Analysis of students' interest in English Reading

\begin{tabular}{|c|c|c|c|c|c|c|c|c|}
\hline \multirow{2}{*}{ Questions } & \multicolumn{2}{|l|}{1} & \multicolumn{2}{|l|}{2} & \multicolumn{2}{|l|}{3} & \multicolumn{2}{|l|}{4} \\
\hline & $\mathrm{CC}$ & EC & $\mathrm{CC}$ & $\mathrm{EC}$ & $\mathrm{CC}$ & $\mathrm{EC}$ & $\mathrm{CC}$ & $\mathrm{EC}$ \\
\hline 1.Are you interested in English reading? & $22.5 \%$ & $45 \%$ & $35 \%$ & $45 \%$ & $30 \%$ & $5 \%$ & $12.5 \%$ & $5 \%$ \\
\hline 2.Do you think English reading is important? & $17.5 \%$ & $37.5 \%$ & $40 \%$ & $50 \%$ & $25 \%$ & $7.5 \%$ & $17.5 \%$ & $5 \%$ \\
\hline $\begin{array}{l}\text { 3.Do you actively answer questions in English } \\
\text { reading class? }\end{array}$ & $15 \%$ & $30 \%$ & $27.5 \%$ & $40 \%$ & $37.5 \%$ & $15 \%$ & $20 \%$ & $15 \%$ \\
\hline $\begin{array}{l}\text { 4.Can you set certain reading goals and try to achieve } \\
\text { them? }\end{array}$ & $15 \%$ & $25 \%$ & $27.5 \%$ & $42.5 \%$ & $40 \%$ & $22.5 \%$ & $17.5 \%$ & $10 \%$ \\
\hline $\begin{array}{l}\text { 5.Do you read English on your own initiative, even if } \\
\text { the teacher doesn't assign you any tasks? }\end{array}$ & $10 \%$ & $22.5 \%$ & $25 \%$ & $55 \%$ & $40 \%$ & $15 \%$ & $25 \%$ & $7.5 \%$ \\
\hline $\begin{array}{l}\text { 6. When you are reading, will you look up a new } \\
\text { word in the dictionary when you don't know it? }\end{array}$ & $17.5 \%$ & $37.5 \%$ & $35 \%$ & $52.5 \%$ & $30 \%$ & $7.5 \%$ & $17.5 \%$ & $2.5 \%$ \\
\hline $\begin{array}{l}\text { 7.After reading, will you find out the sentences you } \\
\text { like in the passage and memorize them? }\end{array}$ & $7.5 \%$ & $30 \%$ & $17.5 \%$ & $50 \%$ & $35 \%$ & $12.5 \%$ & $40 \%$ & $7.5 \%$ \\
\hline $\begin{array}{l}\text { 8.Do you think the purpose of your English study is } \\
\text { not to let English affect your total score? }\end{array}$ & $30 \%$ & $12.5 \%$ & $30 \%$ & $17.5 \%$ & $22.5 \%$ & $42.5 \%$ & $17.5 \%$ & $35 \%$ \\
\hline
\end{tabular}

From the table, we can find that after using the new teaching method, more and more students in the experimental class are interested in English, 45\% of them are very interested in English, which is significantly higher than that in the control class. Moreover, only 5\% of the students think English reading is not important. $30 \%$ of the students in the experimental class would take the initiative to answer questions in English class, an increase of $17.5 \%$ over that before the experiment began. $42.5 \%$ of the students in the experimental class would sometimes set reading goals before class, while only $27.5 \%$ of the students in the control class would do so. When the teacher did not assign tasks, the proportion of extended reading in the experimental class also greatly increased. The rate of dictionary use in the experimental class was as high as $90 \%$, which was much higher than that in the control class and also increased by $40 \%$ since before the experiment began. After the reading class, $30 \%$ of the students often give feedbacks, like finding out the sentences they like in the article and reciting them, while 50\% of the students sometimes do this. After the application of scaffolding teaching, fewer students in the experimental class regard English learning as a task to improve their total score compared with the control class. Therefore, we can conclude that students' interest in English reading is significantly higher than that of the control class. Scaffolding Teaching helps students to build flexible scaffolding instead of rigid memory training, so students' interest in English reading has been greatly improved. 


\subsection{Analysis of Pre-Test and Post-Test}

\subsubsection{Analysis of the Pre-Test of EC and CC}

Table 4. Pre-reading test scores statistics of EC and CC

\begin{tabular}{|c|c|c|c|c|}
\hline Class & $\mathrm{N}$ & Average & Std. Deviation & Std. Error Mean \\
\hline EC & 40 & 18.250 & 5.0830 & 0.8139 \\
\hline CC & 40 & 18.100 & 4.7056 & 0.7440 \\
\hline
\end{tabular}

From the data in the table, we can see that there are 40 people in the experimental class with an average score of 18.25 , and 40 people in the control class with an average score of 18.1. The standard deviation of the experimental class is 5.0830, and the standard deviation of the control class is 4.7056. The standard error mean of the experimental class is 0.8139 , while the standard error mean of the control class is 0.7440 . This indicates that there is no significant difference between the experimental class and the control class in reading scores before the experiment, and the level of reading ability is similar.

\subsubsection{Analysis of the Post-Test of EC and CC}

Table 5. Post-reading test statistics of EC and CC

\begin{tabular}{|c|c|c|c|c|}
\hline Class & N & Average & Std. Deviation & Std. Error Mean \\
\hline EC & 40 & 21.500 & 4.7906 & 0.7671 \\
\hline CC & 40 & 18.400 & 4.9031 & 0.7752 \\
\hline
\end{tabular}

From the data in this table, we can see that the number of the two classes does not change, but the average score of the experimental class is 21.5 , and the average score of the control class is 18.4. Therefore, the average score of the experimental class is higher than that of the control class after the teaching experiment, and the reading ability of the students in the experimental class has been significantly improved.

4.2.3 Comparison and Analysis of the Results of the Pre-Test and the Post Test of the Control Class

Table 6. Paired sample statistical scale of pre-test and post-test results of the control class

\begin{tabular}{|c|c|c|c|c|}
\hline Category & N & Average & Std. Deviation & Std. Error Mean \\
\hline CC Pre-test & 40 & 18.100 & 4.7056 & 0.7440 \\
\hline CC Post-test & 40 & 18.400 & 4.9031 & 0.7752 \\
\hline
\end{tabular}

As can be seen from the table, the average score of the post-test of the control class is 18.4, and the average score of the pre-test is 18.1. The average score of the post-test of the control class is 0.3 points higher than that of the pre-test, indicating that the scores are not greatly improved. In other words, the traditional teaching methods are not conducive to improving students' English reading scores.

4.2.4 Comparison and Analysis of the Results of the Pre-Test and the Post-Test of the Experimental Class

Table 7. Paired sample statistical scale of pre-test and post test results of the experimental class

\begin{tabular}{|c|c|c|c|c|}
\hline Category & $\mathrm{N}$ & Average & Std. Deviation & Std. Error Mean \\
\hline EC Pre-test & 40 & 18.250 & 5.0830 & 0.8139 \\
\hline EC Post-test & 40 & 21.500 & 4.7906 & 0.7671 \\
\hline
\end{tabular}

The statistical data show that the average score of the experimental class is 18.25 in the pre-test, 21.5 in the post-test, and 3.25 in the average difference, which means that the students in the experimental class have made great progress in English reading. However, the average difference of the students in the control class is only 0.3, which proves that the implementation of the scaffolding teaching mode in junior high school English reading class will cultivate and improve the reading comprehension ability of the students more effectively in the experimental class.

Therefore, it can be seen from the above results that the English reading level of the experimental class and the 
control class are similar before the experiment. After three months of teaching experiment, through the comparative analysis of the scores before and after the test of the two classes, it is found that the reading scores of the experimental class and the control class have improved at different ranges, but the progress of the control class is not obvious. The above horizontal and longitudinal analysis and discussion show that the application research of scaffolding teaching mode in experimental class is successful. The scaffolding teaching not only pays attention to the learning of knowledge, but also pays attention to the cultivation of ability, which is conducive to improving the reading level of students. Therefore, the teaching experiment finally achieved good results.

\subsection{Analysis of Interview}

At the end of the three-month experiment, six students of the experimental class were randomly selected for face-to-face interviews. According to the students' English reading post-test results, the six students were divided into three different levels: high, medium and low. Teachers ask some open-ended questions, and students freely express their feelings and thoughts about this teaching mode in the interview, so as to summarize the degree of acceptance of this teaching mode. The interview results are as follows:

Q1: Compared with traditional reading teaching, do you like the scaffolding teaching used by teachers in the reading class?

Three students prefer the scaffolding instruction guidance in English reading class, thinking that their interest in English reading has been enhanced in the new reading teaching mode, and they can really take the initiative to participate in the process of English reading teaching. In class, they can freely express their own ideas and opinions, also can get the teacher or peer assistance in time. Some students think it can help them establish a correct way of learning English, while others think the new teaching method can give them more chances to communicate and discuss with their teachers or peers, and these make lessons more relaxing and comfortable.

S1: I enjoyed the recent reading class very much. In the class, the teacher threw questions at us, which made me more interested in thinking.

S2: When we met with difficulties in the process of reading, the teacher did not help us immediately, but encouraged us to take the initiative to observe carefully, think actively and discuss carefully in group activities. The students all felt that they were very involved in group reading activities.

S3: In the English reading class, the teacher created many activities related to learning to help us build a framework, which made the class more interesting.

Q2: Do you think this kind of reading teaching mode can really improve your English reading performance and reading ability?

Three students believe that scaffolding teaching has a positive impact on their English reading and helps them improve their reading ability. In scaffolding teaching, teachers will build appropriate scaffolds to help students clear their thoughts and solve difficult problems.

S1: I think I have gained a lot from the recent reading lesson. The teacher will guide us to use appropriate context and various scaffold materials to help us analyze the text. Now I am more confident when facing difficult reading articles.

S2: I used to be very slow in doing reading comprehensions, but now I use some reading skills taught by my teacher in reading lessons, which greatly improves my speed of problem solving. I think this is a great progress.

S3: I think I have developed a lot of good reading habits, such as previews before class and reviews after class. Sometimes I also take the initiative to learn about the background of articles.

Q3: Have you gained anything in English reading after applying scaffolding teaching?

Six students think their grades in English reading is one of the biggest gains, having made great progress in reading abilities. Three students think that they learn to set goals and plans, and they will take the initiative to preview and reflect on texts. For longer articles, students learned to use reading strategies to conquer it instead of escape.

S1: I have made great progress in English reading. I spend a lot of my spare time on reading. There is no doubt that my interest in learning English has improved greatly after my teacher using scaffolding teaching.

S2: The biggest gain was that my reading performance improved. I used to have a low level of English reading, so I often flinched when it came to reading, but now I am more confident that reading is not as difficult as I thought it would be. 
S3: After this period of learning, I have learned some reading strategies, which is very helpful for me to do English reading comprehension.

It can be concluded from the interviews that most students approve of the application of the scaffolding teaching mode in English reading lessons. They like and accept this new teaching mode of reading. In classroom activities, students' abilities of independent learning and cooperative learning have been cultivated. Scaffolding teaching mode greatly improves students' interest in English reading, not only cultivating students' good learning habits, but also helping students accumulate English knowledge.

\subsection{Findings}

In this study, scaffolding teaching was applied to junior high school English reading classes. Through the collection and analysis of all relevant scaffolding teaching data, it was found that the basic theory of scaffolding reading teaching could promote junior high school English reading classes. The data analysis conducted in the previous chapter obtained the following findings in practice:

\section{(1) Helpful to enhance students' interest in English reading}

By analyzing the data of the reading interest scale of students before the experiment, it was found that the reading interest of both classes was low. According to the pre-test scores of the experiment, the students in both classes put much emphasis on the grammar of words sentence analysis. After many students finish learning an article, what they get are some key grammar points and key phrases. With the implementation of scaffolding teaching mode, the teacher paid attention to training the students' autonomous learning initiative and focus on students' reading levels of individuals in the experimental class. The teacher designed diversified and multi-level teaching goals, set up various types of scaffolds and created situations. She also used the means such as group discussion and other cooperative learning methods.

\section{(2) Beneficial to improving students' English reading level}

The pre-test data showed that the overall reading ability of the students in the two classes was not high. The traditional translation teaching method emphasized the mastery of words, phrases, sentences and grammatical structures, but did not involve the overall grasp of the main idea and logic of the article. Therefore, the traditional reading teaching mode did not significantly improve the reading ability of the students. After three months of teaching experiment, through the horizontal and vertical analysis of the performance data, it can be seen that the reading ability of the students in the experimental class has been significantly improved. The teacher used a large number of brackets to lead students into the state of independent learning before, during and after class. For example, before class, using similar problem brackets such as brainstorming in the introduction of the class; when students meet with difficulties, the teacher used the picture brackets to help students clarify the thoughts of the text, helped students understand the difficult and key points, and helped students improve their reading levels.

\section{Conclusion}

\subsection{Research Limitations}

This paper, from theory to practice, makes a comprehensive research on scaffolding teaching, and combines three months of teaching experiment, and has achieved a better effect. However, due to the limitation of objective conditions, there are still some shortcomings in this study.

First of all, the scale of the experiment was small. The experiment was conducted in two parallel classes of a junior high school, with a small number of subjects.

Secondly, the time span of experiment is short. The experiment only lasted for three months, so there was insufficient time to really apply the scaffolding teaching mode to English reading classes, so as to further test whether this mode can help junior high school students develop good reading habits.

Finally, in the process of carrying out reading teaching, teachers can not accurately design and build reading scaffolds according to the actual situation of each student.

\subsection{Suggestions}

First of all, more samples should be taken. In this study, only two classes of students from a junior high school participated in the experiment.

Secondly, the span of the teaching experiment doesn't need to be a semester, and it can last a whole year or even three years of junior high school learning. Thus, students can have more time to accept and adapt to the new teaching method, and teachers may have more time to understand the difficulties of students in reading according to their 
actual situation.

Finally, English teachers should provide a variety of reading-related strategic scaffolds in line with the actual level of each student's cognition and development according to the actual performance of each student in reading lessons.

\section{Funding}

The paper was funded by "Projects of Jiangsu Higher Education Reforms". (Grant Number: 2019JSJG323).

\section{References}

Benson, B. K. (1997). Scaffolding Kum is too coming to terms. English Journal, 11, 126-127. https://doi.org/10.2307/819879

Berk, L. (1995). Scaffolding children's learning: Vygotsky and early childhood education. School Psychology International, 19, 189-191.

Cazden. (1979). Vygotsky and the Social Formation of Mind. Cambridge: Harvard University Press.

Dai, X. (2012). An application study of scaffolding theory in senior high school English classrooms. MA thesis of Northwest Normal University.

Du, J. (2005). Construction of scaffolding should be focused in scaffolding teaching. Education Theory and Practice, 25(7), 51-53.

Gao, Y. (2012). An investigation of scaffolding teaching mode based on constructivism. Contemporary Education Science, 19, 62-63.

Gibbons, P. (2002). Scaffolding Language, Scaffolding Learning: Teaching Second Language Learners in the Mainstream Classroom. Butterworth: Heinemann.

Han, C. F. (2010). On improving reading teaching effects through scaffolding teaching. Foreign Language School of Shandong Normal University Journal, 06, 40-43.

He, K. K. (1997). On teaching mode, teaching method and teaching design of Constructivism. Journal of Beijing Normal University, 5, 143-375.

Hobsbaum, A. (1996). Scaffolding in reading recovery. Oxford Review of Education, 22, 17-35. https://doi.org/10.1080/0305498960220102

Hogan, K., \& M, Pressley (1997). Scaffolding Student Learning: Instructional Approaches and Issues. Cambridge, MA: Brookline Books.

Holton, D., \& D, Clarke. (2006). Scaffolding and metacognition. International Journal of Mathematical Education in Science and Technology, 37(2), 127-143. https://doi.org/10.1080/00207390500285818

Liu, Y. (2005). On concept, method and model of scaffolding theory. Journal Guangxi Normal University, 4, 114-121.

Piaget, J. (1954). The Construction of Reality in the Chilren. New York: Basic Books. https://doi.org/10.1037/11168-000

Vygotsky, L. S. (1978). Mind in Society: The Development of Higher Psychological Processes. Cambridge, MA: Harvard University Press.

Wen, Q. F. (2011). Research methods and case analysis of English teaching. Shanghai: Shanghai Foreign Language Education Press.

Wood, D. J., Bruner, J. S., \& Ross, G. (1976). The role of tutoring in problem solving. Journal of Child Psychology and Psychiatry, 17(2), 89-100. https://doi.org/10.1111/j.1469-7610.1976.tb00381.x

Zhang, G. R. (2004). Application of scaffolding theory into English writing teaching. Foreign Language and Foreign Language Teaching, 9, 37-39.

\section{Copyrights}

Copyright for this article is retained by the author(s), with first publication rights granted to the journal.

This is an open-access article distributed under the terms and conditions of the Creative Commons Attribution license (http://creativecommons.org/licenses/by/4.0/). 